\title{
A justiça de transição no Brasil: elementos para pensar a democracia na América Latina
}

\author{
Justice of transition in Brazil: elements to think \\ democracy in Latin America
}

\author{
Doglas Cesar Lucas* \\ Carla Dóro de Oliveira*
}

\section{Resumo}

O presente trabalho teve por finalidade analisar, de forma clara e objetiva, o processo transicional vivido no Brasil por meio do estudo das medidas adotadas pelo Estado no seu processo de redemocratização, especialmente quando em comparação com outros países latino-americanos que também passaram por períodos de exceção, tais como a Argentina, o Chile e o Uruguai. Para tanto, procedeu-se ao estudo acerca da justiça de transição a fim de melhor entender sua origem, finalidade e a forma como deve ser conduzida. Objetivouse, portanto, compreender mais profundamente a forma com que cada um dos países em análise lidou com a superação de um período violento de sua história. $\mathrm{Na}$ análise desenvolvida, buscou-se reconhecer os aspectos positivos e negativos do processo de transição brasileiro, identificando-se, ainda, quais os pontos que mereciam maior atenção. Na metodologia, utilizou-se pesquisa bibliográfica e documental numa abordagem qualitativa, abrangendo a leitura e análise de obras doutrinárias, artigos e jurisprudência. Os resultados do

Doutorado em Direito pela UNISINOS (2008) e Pós-Doutorado em Direito pela Università Degli Studi di Roma Tre (2012). É professor dos Cursos de Graduação e de Mestrado em Direito na Universidade Regional do Noroeste do Estado do Rio Grande do Sul - Unijui e professor no Curso de direito do Instituto Cenecista de Ensino Superior Santo Ângelo -IESA. Professor visitante no mestrado em Direito da URI. ljuí - RS - Brasil. E-mail: doglasl@unijui.edu.br

* Mestranda em Direitos Humanos pela Universidade Regional do Noroeste do Estado do Rio Grande de Sul - Unijuí. Bolsista da CAPES. ljuí - RS - Brasil. E-mail: carladorodeoliveira@gmail. com 
trabalho apontam que medidas adotadas pelo Brasil, apesar de relevantes, ainda são insuficientes para a consolidação da democracia no país, impondose, nesse contexto, a necessidade de implementar a justiça transicional em todos os seus aspectos.

Palavras-chave: América Latina. Democracia. Direitos humanos. Justiça de transição.

\section{Abstract}

This study aims to analyze the Brazilian transitional process, by examing the measures adopted by the State in its democratization, especially while comparing it with other Latin American countries such as Argentina, Uruguay and Chile. With that in mind, the study analyzes the institute of transitional justice, to understand its origins, objectives and procedure. Furthermore, other objective is to understand how each of those countries overcame this traumatic period of its history. From this, this papper aims to recognize the positives and negatives aspects of Brazilian transitional process, identifying the points that deserve more attention. In the methodology, it was used bibliographic and documentary research, in a qualitative approach. Our results indicate that the measures taken until now, although relevant, are insufficient for the consolidation of democracy in our country. In this context, it is necessary to implement the transitional justice in all its aspects.

Keywords: Democracy. Human rights. Latin America. Transitional justice.

\section{Introdução}

"Tudo se esmaecia na névoa. O passado fora anulado, o ato da anulação fora esquecido, a mentira se tornara verdade". Essa frase da célebre obra 1984, de George Orwell, fala muito sobre o tema que nos propusemos a estudar. O ano era outro: em 1964, no Brasil; em 1973, no Chile e no Uruguai; e, em 1976, na Argentina. Sob a suposta alegação de que o comunismo ameaçava interromper o crescimento dos seus países, os militares tomaram o poder e espalharam o medo por meio da tortura e do assassinato. Ao deixarem o comando dessas nações, procuraram impedir qualquer persecução penal dos crimes 
que cometeram, bem como tentaram apagar a história, contar uma versão aprimorada dos acontecimentos, ocultar a verdade. Hoje, depois da redemocratização da Argentina, do Brasil, do Chile e do Uruguai, perguntamo-nos: a redemocratização trouxe melhorias no tratamento das questões envolvendo os direitos humanos nesses países? As perguntas que a ditadura deixou sem resposta foram respondidas pela democracia?

Transcorridos mais de cinquenta anos desde o golpe que instaurou a ditadura militar brasileira, e mesmo após quase trinta anos de vigência da atual Carta Magna, o Brasil ainda vive situações de graves violações dos direitos humanos. O processo transicional brasileiro, embora tenha avançado significativamente nos últimos anos, ainda se encontra em estado de abandono e, em comparação com os países supracitados, estamos atrasados e em débito com a nossa população.

Nesse contexto, o presente trabalho tem por objeto o estudo da justiça de transição em seus variados aspectos a fim de entender quais as medidas adotadas pelo Brasil para superar esse período autoritário, bem como os impactos dessas medidas na construção de uma cultura democrática e de respeito aos direitos humanos.

Indo além, tendo em vista que a ditadura brasileira não consistiu num cenário isolado na América Latina, faz-se interessante averiguar os diferentes caminhos traçados por um ou outro país para sobrepujar esse período de violação de direitos. Nessa lógica, o presente estudo dedicou-se também a analisar os casos argentino, uruguaio e chileno, traçando um paralelo entre eles.

Espera-se, assim, a partir desse estudo integrado sobre a justiça transicional latino-americana, entender como o Brasil e os demais países citados estão superando um capítulo tão traumático de suas histórias, para que possamos contribuir para que os direitos sejam de fato garantidos e respeitados, para que possamos progredir na construção de uma cultura mais democrática e igualitária. 


\section{Um conceito mínimo de justiça de transição e o caso brasileiro}

A justiça de transição traz em seu próprio nome o seu cerne, uma vez que se dedica a conduzir um país à construção de uma cultura democrática após um período de restrição de direitos individuais, trazendo consigo uma gama de medidas aptas a possibilitarem tal mudança. Nesse sentido, de acordo com Paul van Zyl (2011, p. 47), "pode-se definir a justiça transicional como o esforço para a construção da paz sustentável após um período de conflito, violência em massa ou violação sistemática dos direitos humanos".

Para que se torne completo, Paulo Abrão e Marcelo D. Torelly (2011, p. 215) apontam que o processo transicional deve passar por quatro etapas distintas, são elas: "(i) a reparação, (ii) o fornecimento da verdade e a construção da memória, (iii) a regularização da justiça e o restabelecimento da igualdade perante à lei e (iv) a reforma das instituições perpetradoras de violações contra os direitos humanos". Cada qual desempenha relevante e indispensável papel na construção de uma democracia fundada em bases seguras, bem como serve para devolver às vítimas do regime um espaço digno para que possam reconstruir suas vidas.

A primeira dimensão da justiça transicional, a reparação, diz respeito tanto à indenização pelos danos materiais causados às vítimas das violações de direitos humanos quanto à assistência psicológica e medidas de cunho simbólico, tais como memoriais e monumentos (VAN ZYL, 2011). Importante frisar que um aspecto deve ser trabalhado paralelamente ao outro, conciliando-se a reparação pecuniária com a moral. No entanto, houve no Brasil, até pouco tempo, inegável preferência pelo modelo pecuniário de reparação. Segundo Roberta Camineiro Baggio (2011, p. 254), o uso exclusivo desse modelo acarreta um

[...] menosprezo pelos avanços transicionais arduamente conquistados até aqui e o desrespeito em relação aos perseguidos políticos que passam a ser vistos, [...] como 'caçadores de tesouros' às custas do dinheiro público. 
Quanto ao aspecto reparatório, a justiça de transição tem como desafio, mais que possibilitar a autorrealização das vítimas de um regime autoritário, permitir o reconhecimento dessa pessoa, do seu modo de vida e de suas convicções, uma vez que, desse modo, estaria permitindo "aos sujeitos outrora desrespeitados a (re)construção de uma imagem positiva de si mesmos" (BAGGIO, 2011, p. 258). Essa circunstância se faz crucial em face de um regime que classificou como "terroristas" aqueles que se opuseram ao governo, os quais, em larga maioria segundo dados da obra "Brasil: Nunca Mais"1 - foram presos por crimes como militância em organização partidária proibida e que, até hoje, são vistos por uma parcela da população brasileira como criminosos.

Esse quadro tem apresentado melhoras, principalmente após a aprovação da Lei no 10.559/2002, também chamada de nova Lei de Anistia. Regulamentando o art. $8^{\circ}$ do Ato das Disposições Constitucionais Transitórias (ADCT), a dita lei estabeleceu outras medidas de reparação às vítimas do regime ditatorial, além da pecuniária, e instituiu a Comissão de Anistia no âmbito do Ministério da Justiça, a partir da qual foram implantadas as Caravanas da Anistia.

Por meio desse projeto, a Comissão de Anistia se deslocou pelos mais diversos Estados brasileiros "para julgar requerimentos de anistia emblemáticos nos locais onde as perseguições aconteceram, realizando as apreciações em ambientes educativos como Universidades, espaços públicos e comunitários" (SILVA FILHO, 2015, p. 200). O trabalho dessas Caravanas da Anistia é fundamental para a reconstrução da memória e da verdade, mas, principalmente, para a valorização da vítima. Uma das medidas adotadas pela sessão de julgamento das Caravanas é o pedido oficial de desculpas por parte do Presidente da sessão ao anistiado. Com isso,

De acordo com a obra citada, no que concerne ao tipo de acusação que recaía sobre os réus, em primeiro lugar estava a militância em organização partidária proibida (4.935 casos), em segundo lugar, com somente com 1.464 casos, aparecia acusação de participação em ação violenta ou armada. 
[...] corrigiu-se, dentro das balizas legais existentes, o desvirtuamento interpretativo que dava ao texto legal uma leitura economicista, uma vez que a anistia não poderia ser vista como a imposição da amnésia ou como ato de esquecimento ou de suposto e ilógico perdão do Estado a quem ele mesmo perseguiu e estigmatizou como subversivo ou criminoso (ABRÃO; TORELLY, 2011, p. 222).

Esse trabalho realizado pela Comissão de Anistia através das caravanas tem sido largamente elogiado pelos estudiosos do tema, que defendem se tratar de efetiva prática de reparação moral, baseada na valorização do anistiado, por meio do reconhecimento. A partir dessa medida, o Estado vence a barreira da "amnésia" imposta pela Lei de Anistia de 1979 e admite, finalmente, seus erros. O pedido de desculpas é

[...] uma estratégia concreta de valorização do papel daqueles que exerceram com legitimidade seu direito de resistência contra o Estado autoritário, reconhecendo sua importância histórica e contrapondo frontalmente o processo de desvalorização desse grupo na sociedade brasileira. Nesse ato, há uma ressignificação semântica da concepção de anistia, caracterizando tal iniciativa como uma divergência real em relação à ideia de anistia como esquecimento (BAGGIO, 2011, p. 267).

Em se tratando do número de concessões de anistia dadas, cumpre destacar, aliás, que, dos pedidos julgados até 2010 pela comissão, "cerca de 34\% foram indeferidos. Além disso, 41,33\% de todos os requerimentos apreciados pela comissão até dezembro de 2010 foram deferidos, mas sem a concessão de qualquer reparação econômica" (SILVA FILHO, 2015, p. 171).

Medidas como essa dão força ao processo transicional no país, credibilizam a imagem do anistiado político e, outro fator relevante, quebram o silêncio imposto pela Lei de Anistia ao trazerem ao debate a questão das violações aos direitos humanos cometidas durante a ditadura. Aliás, um modelo reparatório que vai além da reparação 
pecuniária ajuda a desconstruir a imagem pejorativa dos anistiados comumente propagada pela mídia.

Outro aspecto que torna ainda mais significativo o trabalho das Caravanas da Anistia é o fato de que, durante as sessões, o anistiando tem a oportunidade de dar seu testemunho sobre os horrores vividos durante a repressão. Tal prática, em um país onde, até o ano de 2011, ainda não tinha sido instalada uma comissão da verdade no âmbito do Executivo, é um acontecimento que merece destaque. Nesse sentido, "ao abrir o espaço público para essas narrativas a comissão contribui para recolocar politicamente no cenário público aqueles que foram expulsos da comunidade política, violados, agredidos e desumanizados" (SILVA FILHO, 2015, p. 177).

Aliás, diferentemente do que aconteceu nos países vizinhos, notadamente na Argentina, onde o primeiro presidente eleito democraticamente após a ditadura militar instituiu uma comissão da verdade para a apuração dos fatos ocorridos durante o regime autoritário²; em nosso país, somente com a Lei $n^{\circ} 12.528 / 2011$ é que foi criada, no âmbito do Poder Executivo, a Comissão Nacional da Verdade (CNV), que tem por finalidade examinar e esclarecer as graves violações de direitos humanos praticadas no período ditatorial, de modo a efetivar o direito à memória e à verdade histórica, e promover a reconciliação nacional. Antes disso, o Estado brasileiro promoveu outras ações, mas nenhuma tomou a magnitude da CNV, alçando o tema da busca pela memória e pela verdade ao centro do debate nos principais veículos midiáticos do país.

Ao tratar do tema, Silva Filho (2011, p. 292) observa que o "esquecimento é antes um obstáculo do que uma premissa para a reconciliação". Na visão do autor, somente com o reconhecimento dos fatos ocorridos, com o esclarecimento da verdade, com a construção da memória e com o reconhecimento da vítima enquanto agente político

Na Argentina já em 1983 o Presidente Raúl Alfonsín instituiu a Comissão sobre o Desaparecimento Forçado de Pessoas (CONADEP). 
relevante na luta contra um regime injusto e opressor é que se pode superar esse triste capítulo da história brasileira, quando, aí sim, o esquecimento finalmente servirá como aliado no processo de luto.

Importante estudo foi conduzido por Olsen, Payne e Reiter. Os pesquisadores concluíram, ao analisarem os números da Base de Dados da Justiça de Transição (TJDB), que as anistias não desempenham um papel de todo negativo na justiça transicional se combinadas com outras medidas. Ademais, a adoção isolada das comissões da verdade pode gerar resultados contraproducentes, e que o "seu sucesso depende da combinação das comissões de verdade com os julgamentos e as anistias" (OLSEN; PAYNE; REITER, 2011, p. 561).

Tais dados reforçam a ideia de que uma justiça de transição lastreada apenas em um sistema reparatório que privilegia a reparação pecuniária e em comissões da verdade - tardiamente instauradas - não é suficiente para o avanço dos direitos humanos e o fortalecimento da democracia. Diante disso, os dados coletados durante referida pesquisa comprovam que

[...] as anistias não são necessariamente perigosas para a democracia e os direitos humanos como a abordagem contestadora argumenta. [...] Apenas as comissões de verdade tendem a resultados negativos, mas apenas quando os Estados a utilizam em benefício próprio. (OLSEN; PAYNE; REITER, 2011, p. 561).

Isso significa que "as anistias poderão vir antes e serem depois afastadas para que ocorram os julgamentos (como no caso argentino), ou que as anistias convivam com a realização de alguns julgamentos (como no caso chileno e uruguaio)" (SILVA FILHO, 2015, p. 66). Logo, frisa-se que, em dado momento histórico, as anistias podem surgir como a única forma de um governo ditatorial "deixar" o poder. Ademais, que isso não pode servir de obstáculo para que essas anistias não sejam nunca contestadas. Para além, que nem sempre uma lei de anistia precisa ser revogada ou anulada para que a responsabilização dos agentes públicos que cometeram crimes de lesa-humanidade 
possa acontecer, uma vez que, como no caso uruguaio, pode-se optar pela responsabilização de parte dos agentes envolvidos na violação sistemática aos direitos humanos. Inadmissível é a absoluta negativa, por parte do Estado, dessa dimensão da justiça transicional.

De acordo com Paul van Zyl (2011, p. 49-50), "os julgamentos podem servir para evitar futuros crimes, dar consolo às vítimas, pensar um novo grupo de normas e dar impulso ao processo de reformar as instituições governamentais, agregando-lhes confiança”. O que se deve considerar é que a responsabilização dos agentes repressores é somente uma das dimensões da justiça transicional e não pode, de modo algum, ser encarada como o aspecto mais relevante, devendo vir sempre aliada dos demais âmbitos do processo de transição.

A estagnação das instituições públicas desde a ditadura militar é fator que contribui para a continuidade da violação dos direitos individuais, de modo que esse aspecto da justiça de transição também não pode ser deixado de lado. O que se nota é que, até hoje, o Poder Judiciário é conservador, o Exército brasileiro ainda não reconhece a violação sistemática aos direitos humanos perpetradas durante o regime militar e, por fim, a violência permanece sendo o modus operandi das instituições de segurança pública no país. Nesse sentido, a reforma das instituições pode trabalhar como aliada da responsabilização dos agentes públicos.

Em se tratando do Poder Judiciário, seu conservadorismo pode ser observado por diferentes enfoques. No entanto, urge dar destaque ao julgamento da ADPF $n^{\circ} 153$ pelo Supremo Tribunal Federal. Nessa decisão, a maioria dos Ministros sequer menciona o direito internacional na análise do fato, mesmo que o assunto verse sobre direitos humanos, matéria amplamente amparada por tratados e convenções de direito internacional.

Quanto ao Exército, até hoje se espera um pedido oficial de desculpas pelos crimes de lesa-humanidade cometidos durante a ditadura militar. Ademais, até 2010, as Forças Armadas comemoravam 
o dia do golpe que deu início ao regime ${ }^{3}$. Além disso, em 2010, o jornal Folha de São Paulo denunciou a adoção, nos Colégios Militares, de um livro de história que ensinava a "louvar a ditadura", segundo o qual o golpe de 1964 foi uma "revolução democrática"4.

Mais recentemente, em junho de 2014, as Forças Armadas perderam novamente a oportunidade de reconhecer os erros cometidos no passado e colaborar com o trabalho desenvolvido pela CNV. Conforme noticiado pela Carta Capital, em resposta aos pedidos de sindicância formulados pela comissão, as Forças Armadas negaram ter havido "desvio de finalidade" em instalações onde houve tortura durante a ditadura (como o DOI-CODI de São Paulo) ${ }^{5}$.

Para demonstrar os efeitos da falta da reforma das instituições públicas no Brasil, é imperioso apresentar os dados colhidos pela organização não governamental Anistia Internacional (Al) nos Informes 2014/2015 sobre "O estado dos direitos humanos no mundo". Na pesquisa, a Al traz informações relativas à violação dos direitos humanos nos mais diversos países onde atua. O informe é dividido por país, sendo que, logo na introdução relativa ao Brasil, registra-se que "prosseguiram as denúncias de graves violações dos direitos humanos, como os homicídios cometidos pela polícia e a tortura ou outros maus-tratos de pessoas detidas" (ANISTIA INTERNACIONAL, 2015, p. 72). Segundo o relatório, nas manifestações ocorridas no ano de 2013, "a Polícia Militar (PM) recorreu com frequência à força excessiva e desnecessária para dispersar manifestantes" (ANISTIA INTERNACIONAL, 2015, p. 73). Aliás, em se tratando da segurança pública, a Al também demonstrou preocupação, registrando que,

3 Reportagem de Bruno Góes veiculada pelo jornal O Globo em 31 de março de 2011 dá conta que o Exército decidiu abolir as comemorações ao golpe de 64. Disponível em: <http://oglobo. globo.com/politica/exercito-abole-comemoracao-do-golpe-de-64-mas-clubes-militares-prestamhomenagem-data-2802824>. Acesso em: 11 jun. 2015.

4 Reportagem de Angela Pinho publicada em 13 de junho de 2010 pela Folha de São Paulo. Disponível em: <http://www1.folha.uol.com.br/fsp/cotidian/ff1306201018.htm>. Acesso em: 11 jun. 2015.

5 Notícia publicada em 18 de junho de 2014 pela Carta Capital. Disponível em: < http://www. cartacapital.com.br/sociedade/forcas-armadas-negam-desvio-de-finalidade-em-instalacoesonde-houve-tortura-8372.html>. Acesso em: 11 jun. 2015. 
[...] segundo estatísticas oficiais, 424 pessoas foram mortas pela polícia durante operações de segurança no estado do Rio de Janeiro em 2013. No primeiro semestre de 2014, houve um aumento do número de mortes nessas circunstâncias, quando a polícia matou 285 pessoas, $37 \%$ a mais que no mesmo período de 2013 (ANISTIA INTERNACIONAL, 2015, p. 73).

Esses números reforçam a tese de que a impunidade e a falta de uma reforma nas instituições públicas brasileiras após o período ditatorial contribuem para uma cultura de violência em nosso país. Os órgãos da segurança pública, em vez de fazerem cessar a violência com que tratavam os presos políticos na ditadura militar, apenas mudaram de foco. Agora, o "inimigo estatal" é o pobre, o negro e o insubordinado. De acordo com Silva Filho (2011, p. 282), a falta de uma transição adequada "se reflete na continuidade da extrema violência empregada pelas forças de segurança pública no país, e em especial da tortura como método de investigação criminal”.

Aliás, quanto ao uso da tortura como método de investigação criminal, a Anistia Internacional conduziu um novo estudo chamado Actitudes respecto a la tortura, pelo qual entrevistou 21.221 pessoas de vinte e um países. Na pesquisa, diante da seguinte afirmação: "se as autoridades de meu país me colocassem sob custódia, tenho confiança de que estaria a salvo da tortura", perguntou-se a cada entrevistado se: concordava totalmente, concordava parcialmente, discordava em parte ou discordava totalmente.

O resultado da pesquisa indicou que $80 \%$ dos brasileiros discordam total ou parcialmente dessa afirmação, 18\% concordavam (total ou parcialmente), enquanto $2 \%$ não souberam ou não quiseram responder. O Brasil foi o país onde o medo da tortura foi mais alto, bem à frente do México, segundo colocado, onde $64 \%$ dos entrevistados discordaram, total ou parcialmente, da afirmação supracitada.

Frisa-se que a pesquisa foi realizada em outros países latinoamericanos que passaram por ditaduras, mas que, no entanto, 
apresentam um processo transicional mais avançado que o brasileiro. $\mathrm{Na}$ Argentina, por exemplo, 49\% dos entrevistados discordaram da afirmação, enquanto 34\% concordaram; já no Chile, $30 \%$ dos entrevistados discordaram da afirmação, enquanto 45\% concordaram. Isso demonstra um índice muito maior de confiança nas instituições de segurança pública por parte dos vizinhos que implementaram a justiça transicional de forma mais completa ${ }^{6}$.

Como já foi dito, a justiça de transição se faz de diferentes aspectos e é quando essas dimensões são trabalhadas em conjunto que se aumentam as chances de obtenção de avanços significativos na valorização dos direitos humanos e no fortalecimento da democracia. Nesse sentido, "a ausência de uma adequada transição política contribui para que a democracia não se desenvolva, para que ela fique isolada em um discurso democrático ao qual corresponde, em verdade, uma prática autoritária" (SILVA FILHO, 2011, p. 282-3).

Desse modo, é imperioso lutar para que o processo transicional se complete no país, de modo que se efetive a reparação (não apenas pecuniária, mas também moral das vítimas de violações aos direitos humanos), a busca por verdade e memória (a exemplo do trabalho conduzido pela CNV, embora com a relutância das Forças Armadas), a responsabilização dos agentes públicos (dentro dos limites possíveis) e paralelamente uma reforma das instituições democráticas (para o seu fortalecimento).

\section{Ações similares, reações desiguais: um estudo comparado entre as ditaduras vividas no Brasil e na Argentina}

Infelizmente, o Brasil não se encontra num cenário isolado em se tratando de graves violações aos direitos humanos levadas a cabo por

\footnotetext{
6 Pesquisa completa disponível em: <https://anistia.org.br/direitos-humanos/publicacoes/pesquisaglobal-percepcoes-sobre-tortura/>. Acesso em: 11 jun. 2015.
} 
um governo militar contra a população civil. Basta olharmos as nações vizinhas para encontrarmos histórias muito semelhantes às vividas por nós, brasileiros, durante a ditadura. É interessante destacar que as histórias argentina e brasileira se aproximam e se afastam em diversos pontos. Nas palavras de Guilhermo J. Yacobucci (2011, p. 22), "la historia política del Siglo XX en la Argentina estuvo signada no solo por los grandes cambios sociales también por la violencia que encontró, en los recurrentes golpes de Estado, uno de los aspectos más destacados". Essa caracterização dita não destoa da experiência vivida pelo Brasil, que também passou por golpes de Estado.

Ao explicar de que forma se dava a repressão na ditadura Argentina, o autor relata que o uso da violência era contínuo e que logo o governo começou a fazer uso do desaparecimento forçado de pessoas (YACOBYCCI, 2011). Os métodos utilizados pelo governo argentino para reprimir os opositores eram tão parecidos com aqueles utilizados pelo governo ditatorial brasileiro que os relatos sobre as práticas lá utilizadas poderiam facilmente ser tomados como acontecimentos relativos ao Brasil. Nesse sentido, explica José Maria Gomes (2008, p. 105), todos os regimes ditatoriais "convergiam no objetivo estratégico último de eliminar as ameaças subversivas à ordem social estabelecida e redefinir os termos de inserção dos capitalismos periféricos na economia mundial, num processo de 'modernização conservadora'”.

Aliás, assim como no Brasil, o governo ditatorial argentino também se preocupou em silenciar todos que considerava inconvenientes: militantes, professores e clérigos. Até mesmo as Madres de Plaza de Mayo sentiram a pesada mão do Governo ditatorial. Apesar dessa semelhança, no caso argentino, os números da repressão é que causam espanto. Conforme expõe Claudia C. Tomazi Peixoto (2011, p. 18), estudos indicam que a ditadura argentina, que se estendeu de 1976 a 1983, "resultou em 30 mil mortos e desaparecidos, segundo a Associação das Mães da Praça de Maio, e em torno de 18 mil segundo dados oficiais". No Brasil (1964-1985), segundo dados da Comissão Nacional da Verdade, a ditadura teria deixado o saldo de 434 mortos e desaparecidos. 
Nessa senda, apesar dos regimes brasileiro e argentino terem suas similitudes, também se distinguem em alguns pontos. Enquanto na Argentina o desaparecimento forçado era o tratamento dispensado, via de regra, aos indivíduos que o governo considerava "subversivos"; no Brasil, o método preferido era a aplicação da tortura aos presos políticos e, embora o desaparecimento forçado também fosse recorrente, foi menos praticado em comparação com o país vizinho. Essa distinção, por sua vez, teve relevante impacto no número total de mortos e desaparecidos durante o regime ditatorial em cada país, o que, infelizmente, acabou por influenciar o modo como cada Estado tratou da sua justiça de transição.

Assim como no Brasil, o governo ditatorial da Argentina editou, antes de deixar o poder, uma lei de anistia, a Lei n²2.924/1983 (Lei de Pacificação Nacional), visando à impunidade dos crimes perpetrados pelos seus agentes durante o regime. Conforme Pablo F. Parenti (2011, p. 42), a norma foi

[...] denominada comumente como 'Lei de autoanistia', mediante a qual foram declaradas extinguidas 'as ações penais emergentes dos delitos cometidos com motivação ou finalidade terrorista ou subversiva, desde 25 de maio de 1973 até 17 de junho de 1982' e 'todos os fatos de natureza penal realizados na ocasião ou com motivo do desenvolvimento de ações dirigidas a prevenir, conjurar ou pôr fim às referidas atividades terroristas ou subversivas, qualquer tivesse sido sua natureza ou o bem jurídico lesionado'.

É a partir de então que as semelhanças entre a experiência argentina e brasileira começam a rarear. Na Argentina, o presidente democraticamente eleito, Raúl Alfonsín, promoveu diversas medidas para garantir uma justiça de transição adequada. Aliás, o governo de Alfonsín foi o que

[...] foi mais longe na proposta de 'solução': revogou a lei de auto-anistia, criou uma comissão de investigação para apurar a verdade do acontecido com os desaparecidos (a Comisión Nacional sobre la Desaparición de las Personas 
- CONADEP -, presidida pelo escritor Ernesto Sábato) e submeteu as três juntas militares da ditadura ao julgamento penal na justiça civil, junto com a cúpula das organizações guerrilheiras, além de outras medidas de reparação e promoção dos direitos humanos (ratificação de tratados internacionais, educação formal em escolas colégios e universidades, etc.) (GOMES, 2008, p. 110).

Ainda conforme Parenti (2011, p. 43), o Congresso argentino, por sua vez, "sancionou, em 22 de dezembro de 1983, a lei 23.040, que revogou por inconstitucionalidade e declarou irremediavelmente nula a lei de fato 22.924". Seguindo no caminho da investigação e do esclarecimento das graves violações aos direitos humanos, o Judiciário argentino ratificou a decisão do Legislativo. "La Corte Suprema de Justicia argentina (CSJN) legitimó la anulación de esa norma de facto, restándole entonces toda eficacia a sus actos de manera retroactiva" (YACOBUCCI, 2011, p. 26).

No entanto, a punição dos responsáveis pelos crimes de lesahumanidade cometidos durante a ditadura argentina enfrentou dificuldades e resistência por parte dos integrantes das Forças Armadas. Diante da imposição de algumas condenações pelos crimes cometidos por militares durante do regime ditatorial, o governo, pressionado, impediu a continuação da persecução penal a partir da aprovação, pelo Legislativo, das Leis de Ponto Final (Lei n²3.492/1987) e de Obediência Devida (Lei n² 23.521/1988) (YACOBBUCI, 2011, p. 27).

Aedição das referidas leis marcou o encerramento dos julgamentos penais dos crimes ocorridos durantes a ditadura militar na Argentina. Cumpre frisar que os dispositivos legais foram editados durante um governo democrático e que "a lei de obediência devida foi convalidada poucos dias depois pela Corte Suprema de Justiça da Nação" (PARENTI, 2011, p. 44), a mesma corte que havia se manifestado favorável à invalidação da lei de anistia argentina.

Contudo, com a mudança na constituição argentina e a consequente incorporação dos tratados internacionais de direitos humanos ao 
ordenamento interno, a Corte Suprema argentina, no julgamento do caso Simon, baseando-se na decisão da Corte Interamericana de Direitos Humanos no caso Barrios Altos vs. Peru, entendeu que, em face das mudanças percorridas pelo direito argentino, as Leis de Obediência Devida e Ponto Final não podiam continuar em vigência, o que possibilitou a retomada do julgamento dos crimes cometidos durante a ditadura (YACOBUCCI, 2011). Além disso, para encerrar a questão, o Poder Legislativo privilegiou o respeito aos direitos humanos e, a partir da Lei $n .^{\circ} 25.779 / 2003$, seguiu o entendimento da Corte e declarou a nulidade das leis supramencionadas (PARENTI, 2011).

Em se tratando dos julgamentos dos crimes cometidos pelos agentes da repressão durante a ditadura militar argentina, Peixoto (2011, p. 16) relata que, até o mês de maio de 2011, "807 pessoas foram/ estavam sendo julgadas, das quais 212 foram condenadas".

Não se duvida que a reabertura dos processos pelos crimes cometidos durante o período ditatorial na Argentina é tarefa árdua, que exige muito esforço por parte de todas as autoridades envolvidas. No entanto, tal argumento não pode servir de entrave à persecução e à investigação dos fatos. Como bem destaca Yacobucci (2011, p. 44)

[...] el camino escogido por la Argentina no tiene marcha atrás. Ciertamente deberán crearse medios, ajustarse esquemas de trabajo y limitar la carga ideológica en el desenvolvimiento de los juicios para alcanzar el verdadero significado de la tragedia vivida por nuestro país.

Por outro lado, a persecução penal das graves violações aos direitos humanos perpetradas durante a ditadura militar não deve, de modo algum, ser encarada como "revanchismo". Pelo contrário, a busca da verdade permitirá a superação do assunto e o enfrentamento das questões traumáticas.

Desde a instauração de uma comissão da verdade até o julgamento dos crimes contra a humanidade cometidos durante o regime ditatorial, fica evidente que os caminhos escolhidos pelo Brasil e pela Argentina foram opostos. Embora os defensores da anistia ampla e 
irrestrita defendam que o regime ditatorial vivido em nosso país foi mais brando do que o dos outros países latinos, pois matou menos, isso não pode jamais servir de argumento para a ocultação e o esquecimento de fatos tão importantes e de tamanha magnitude para a construção e elucidação de nossa própria história.

Precisamos ter em mente que a morte de um indivíduo pelo Estado não é menos cruel e perigosa para a democracia de um país do que o assassinato de duas ou três pessoas, mas também que é cruel e perigosa em si mesma. Ademais, além de ser um crime, o cerceamento da liberdade de seus cidadãos é uma ameaça constante a todos os demais componentes de uma sociedade. Portanto, quando aceitamos que tais violações caiam no esquecimento, estamos permitindo que essas violações venham a se repetir. Nesse sentido, a anistia, ao contrário do senso comum, não serviu para promover a paz social, mas para colocar no esquecimento as violações aos direitos humanos perpetradas, deixando muitas perguntas sem resposta e muitas famílias sem paz.

\section{4 “Lá e de volta outra vez": as lições da justiça de transição no Chile e no Uruguai}

As experiências uruguaia e chilena apresentam diferenças significativas em relação à vizinha Argentina. No entanto, percebe-se que, mesmo que tardiamente, esses países estão implementando sua justiça transicional de forma mais completa que o Brasil, seguindo o caminho do respeito aos direitos humanos e atendendo ao que dispõem os tratados internacionais sobre o tema.

A ditadura civil-militar no Uruguai estendeu-se de 1973 a 1984, tendo sido iniciada a fim de evitar suposta ameaça comunista. Curiosamente, o então presidente democraticamente eleito, Juan Maria Bordaberry, continuou como chefe de Estado até 1976, quando foi, então, deposto pelos militares. Frisa-se que, assim como em outras ditaduras 
do Cone Sul, a violação dos direitos individuais foi prática costumeira na ditadura uruguaia (PALERMO, 2014).

Findo o regime autoritário, o país passou por uma transição negociada ${ }^{7}$ - assim como no Chile -, de forma que os militares só entregaram o poder "cuando no hubiera ninguna etapa de revisionismo de ningún miembro de las fuerzas armadas o de la policía, que hubiera actuado en cumplimiento de ordenes" (PALERMO, 2014, p. 159-60).

Assim, os primeiros passos da democracia uruguaia apoiaramse em práticas de esquecimento e na impunidade dos agentes do regime autoritário. Para garantir a dita impunidade, "a fines de 1986 el Parlamentó promulgó la Ley 15.848, denominada Ley de Caducidad de la Pretensión Punitiva del Estado" (PALERMO, 2014, p. 163), desse modo, toda decisão judicial ficava submetida ao crivo do Executivo. Assim, segundo Jo-Marie Burt (2011, p. 321), a Lei da Caducidade "acabou com os esforços do Estado de processar criminalmente os membros das Forças Armadas acusados de violações de direitos humanos".

Para piorar um cenário que já era desanimador, a Suprema Corte de Justiça uruguaia (SCJ) declarou a constitucionalidade da Lei $\mathrm{n}^{\circ}$ 15.848/86, "en una sentencia fundamentada principalmente con argumentos políticos" (PALERMO, 2014, p. 163-4). Nessa perspectiva, é importante destacar que essa atitude não destoa da decisão proferida por nossa Suprema Corte, em 2010, nos autos da ADPF n 153/2010. Nessa sentença, o Supremo Tribunal Federal (STF) declarou que a anistia brasileira era decorrente de um "acordo político" que uniu todos os setores da sociedade à época em que foi aprovada, e que, portanto, deveria continuar gerando os efeitos então pretendidos. O STF preferiu, assim, dar legitimidade para esse "acordo" firmado sob a mira da baioneta, do que fazer valer os tratados sobre direitos humanos dos quais o Brasil é signatário.

Interessante, nesse contexto, fazer referência à transição "lenta, gradual e segura" proposta pelo General Ernesto Geisel, que visava justamente garantir a impunidade dos agentes da repressão depois da redemocratização do Brasil. 
O que, todavia, é mais contraditório no caso uruguaio é o fato de a Lei de Caducidade ter sido aprovada por um referendo popular no ano de 1989 (PALERMO, 2014). No entanto, observa Palermo (2014, p. 164), se "esta solución contaba con el beneplácito del sistema democrático y de la mayoría de la ciudadanía ella no cumplía con todos los estándares internacionales y supranacionales de protección de los derechos humanos y de las minorias", tendo sido, por isso, questionada pela Comissão Interamericana de Direitos Humanos.

Uma primeira tentativa de reconciliação foi adotada no governo do presidente Jorge Batle, quando houve a criação da Comissão para a Paz (Resolução n 858/2000). Essa comissão tinha competência para averiguar o desaparecimento forçado de pessoas ocorrido durante o regime autoritário. Todavia, essa comissão foi controversa, visto que muitos "permaneceram críticos a respeito de seu alcance limitado (ela não investigou outros crimes, como assassinatos, detenção arbitrária, e o uso generalizado de tortura de prisioneiros políticos)" (BURT, 2011, p. 323). Nesse sentido, observa-se que o trabalho da Comissão para a Paz, apesar de relevante, demonstrou-se insuficiente.

A persecução penal dos crimes cometidos pelos agentes da repressão só teve inicio em 2005, com "un cambio de interpretación de la ley de caducidad (15.848) por parte del gobierno de Tabaré Vázquez (2005-2010), liberando casos puntuales del amparo de esta especie de 'amnistía” (PALERMO, 2014, p. 166). Com essa mudança interpretativa, Bordaberry, o presidente à época do golpe de Estado, foi julgado e condenado "a la máxima pena que existe en Uruguay (treinta años de penitenciaría) y a quince años de medidas de seguridad eliminativas, por ser considerado un criminal peligroso (Art. 92 CP)" (PALERMO, 2014, p. 168).

Somente em 2009 a SCJ declarou a inconstitucionalidade de parte da Lei de Caducidade, sem, contudo, outorgar efeito erga omnes à decisão. Assim, "la ley continúa vigente en el ordenamiento jurídico uruguayo. En ese sentido, el Poder Ejecutivo tiene la potestad de decidir qué casos pueden ser investigados y cuáles están amparados por la 
caducidad" (PALERMO, 2014, p. 170). Portanto, apesar dos avanços, "a Lei da Caducidade continua a representar um obstáculo para a investigação e o processo de centenas de outros casos [...] uma vez que tais decisões apenas se aplicam a determinados casos sob revisão e não possuem um efeito mais geral" (BURT, 2011, p. 325-326).

Outro momento destacável no processo transicional uruguaio foi a declaração, pela Corte Interamericana de Direitos Humanos (CIDH), da incompatibilidade da Lei de Caducidade perante a Convenção Americana de Direitos Humanos (CADH). Nesse caso, "la CIDH no solo condena al Estado uruguayo por mantener vigente la ley sino que da un paso más y determina la imputación penal que corresponde al caso en cuestión" (PALERMO, 2014, p. 170).

Nesse contexto, uma proposta de reforma constitucional a fim de revogar a Lei de Caducidade foi submetida a plebiscito, tendo sido, todavia, rejeitada pela população. Em seguida, o Congresso uruguaio ratificou a Lei de Caducidade. Somente com um decreto presidencial emitido em 2011 é que foram revogados "los actos administrativos de gobiernos democráticos anteriores que excluyeron a determinadas personas de una investigación penal en aplicación del Art. 3 de la ley de Caducidad" (PALERMO, 2014, p. 172), tendo sido retomados, portanto, os julgamentos. Em consequência, o Congresso do Uruguai aprovou uma lei, "em outubro de 2011, que não só anula a Lei da Caducidade como também estabelece que crimes cometidos durante a ditadura são crimes contra a humanidade e, portanto, normas de prescrição não se aplicam" (BURT, 2011, p. 326).

O que se nota do processo de transição vivido no Uruguai é que, mesmo contra o senso comum manifestado pela população por duas consultas populares - o referendo de 1989 e o plebiscito de 2009 a Lei de Caducidade foi finalmente revogada e, então, os julgamentos puderam enfim começar.

As semelhanças que podemos indicar entre o caso brasileiro e o uruguaio são, inicialmente, a falta de reivindicação por parte da população da implementação completa da justiça de transição em nosso 
país. Além disso, assim como ocorreu no Uruguai, a atuação do Poder Executivo é mais marcante que a dos demais poderes, e também acaba por incentivá-los. No Uruguai, graças ao decreto presidencial emitido em 2011, o Congresso acabou por revogar a Lei da Caducidade. No Brasil, observa-se que o Executivo é a instância que tem dado maior importância às decisões da CIDH, tendo instalado, em 2011, a Comissão Nacional da Verdade em decorrência da condenação do país no caso Gomes Lund e outros vs. República Federativa do Brasil.

A ditadura chilena (1973-1990), sob o comando de Augusto Pinochet, por sua vez, foi uma das mais sangrentas da história latinoamericana. Ao assumir o poder, o governo ditatorial passou a atuar com uma lógica de guerra interna, mesmo que não houvesse grupos armados organizados para derrubar o regime autoritário no país (PEREIRA, 2011). Além da violação de direitos sociais e políticos, a violência física - tortura e desaparecimentos - também era comum. Nas palavras de Pamela Pereira (2011, p. 291), milhares de pessoas "eram conduzidas a estádios e outros lugares transformados em prisões, onde frequentemente os detidos eram interrogados mediante métodos de tortura, e, além disso, foram instalados centros clandestinos de detenção e tortura". Para mais, o golpe militar "além de derrubar o governo do Presidente Salvador Allende, no âmbito institucional dissolveu o Parlamento, proscreveu os partidos políticos, sindicatos e demais organizações sociais" (PEREIRA, 2011, p. 291).

Importante destacar que, assim como nos demais países aqui estudados, a transição para a democracia também foi controlada pelo governo ditatorial chileno que aprovou, em 1978, antes de deixar o poder, uma lei de anistia. Consequentemente, "nenhum oficial sênior foi julgado por violações dos direitos humanos no Chile no período posterior à transição democrática" (ENGSTROM, 2011, p. 113).

Mesmo com o fim do regime militar, explica Naomi Roth-Arriaza (2011, p. 145), "o Chile foi incapaz de abolir legislativamente sua lei de anistia, apesar de ordens diretas da Corte Interamericana para isso ser feito", situação semelhante à vivida no Brasil e no Uruguai. Por temer 
uma reação militar, o presidente Patricio Aylwin não constestou a lei de anistia de 1978, no entanto, criou uma comissão da verdade para a investigação dos crimes ocorridos na ditadura militar (BURT, 2011). Desse modo, "o governo Aylwin patrocinou um extensivo processo de 'divulgação da verdade' e reconciliação por meio de uma série de mecanismos, incluindo uma comissão de verdade oficial" (ENGSTROM, 2011, p. 113).

Importante salientar que, de acordo com Pereira (2011), a Suprema Corte chilena serviu de suporte ao governo autoritário durante o regime ditatorial, e somente após a redemocratização do país, com a mudança dos ministros, é que a Corte passou a atuar no interesse da democracia e em prol dos direitos das vítimas da repressão. Assim, quando da prisão de Pinochet em Londres, em 1998, determinada por um juiz espanhol - motivada no princípio da extraterritorialidade da lei penal em matéria de crimes contra a humanidade -, o quadro já era mais propício para o início dos julgamentos criminais no Chile.

Nesse sentido, a prisão do ditador aliada ao trabalho incansável das vítimas da ditadura e das organizações de defesa dos direitos humanos no Chile foram fatores que contribuíram de forma significativa para o início das responsabilizações judiciais dos agentes militares. Nesse sentido, muito embora a lei de anistia chilena continue em vigor, ela não impõe obstáculo à justiça. Conforme Burt (2011, p. 320), "entre 2000 e maio de 2011, 773 membros ou ex-membros das forças de segurança do Estado foram processados ou sentenciados por crimes de direitos humanos, com 245 sentenças (confirmadas pela Suprema Corte) até a data". Ademais, Roth-Arriaza (2011, p. 146) ressalta que "quase $37 \%$ das vítimas identificadas mortas ou desaparecidas agora possuem ação judicial a seu favor".

Em dezembro de 2006, Pinochet morreu sem ter sido julgado pelos crimes dos quais foi acusado. No entanto, o caso de Pinochet forçou a abertura da questão da contínua impunidade por violações de direitos humanos no Chile, não obstante os esforços de sucessivos governos para colocar a questão de lado. Como um resultado direto 
disso, o governo criou novos espaços de discussão com os grupos da sociedade civil e as Forças Armadas, incluindo a Mesa de Diálogo, e, mais tarde, estabeleceu a segunda comissão da verdade (a Comissão Valech) para examinar casos de prisioneiros políticos e de tortura que não haviam sido incluídos no mandato da primeira comissão da verdade (BURT, 2011).

Nessa lógica, é possível observar que o Chile, em comparação com o Brasil, também vem implementando de forma mais eficaz e comprometida a justiça transicional, dando azo não apenas à verdade e à memória, mas também à reforma das instituições e à busca pela justiça por meio dos julgamentos dos militares envolvidos em crimes contra a humanidade.

Ante o exposto, observa-se que, embora tardiamente, os dois países deram ensejo à execução do processo de transição de forma mais completa, iniciando a responsabilização dos agentes envolvidos em violações aos direitos humanos, o que vem sendo negado pelo Estado brasileiro, especialmente em decorrência da interpretação do Supremo Tribunal Federal sobre a Lei de Anistia. É interessante observar que, tanto no Uruguai quando no Chile, as leis de anistia continuam em vigor, o que, contudo, não tem servido de entrave à persecução penal dos envolvidos em violações aos direitos humanos durante as ditaduras militares.

\section{Conclusão}

Assim como temos que enfrentar nossos medos para superálos, também precisamos enfrentar e esclarecer os crimes cometidos no país durante a ditadura militar brasileira para deixarmos para trás esse capítulo tão nefasto de nossa história. O esquecimento só pode acontecer em decorrência do luto, e, para que possamos viver o luto, temos que enterrar nossos cadáveres. Só conseguiremos sepultar esse passado quando ele for finalmente desvendado, quando sua história for enfim contada, quando a verdade for reconstruída. 
No Brasil, a justiça de transição anda a passos lentos, quase para. Inicialmente, valorizando a reparação pecuniária, o Estado esqueceu os demais aspectos do processo transicional, o que acabou transformando os anistiados em figuras mal vistas pela população, tendo sido com frequência chamados pela mídia de caçadores de tesouros em busca da "bolsa ditadura". Mais recentemente, com as Caravanas da Anistia e a instalação e o relatório da $\mathrm{CNV}$, a reparação moral e a busca pela verdade e pela memória também tiveram seu espaço no processo de transição brasileiro.

No entanto, a segurança pública continua atuando com extrema violência em nosso país, escolhendo os "criminosos" conforme estereótipos muito bem categorizados: se durante a ditadura o alvo era o militante, o "subversivo"; hoje é o negro, o jovem pobre da periferia. Nesse sentido, a reforma das instituições é medida imperativa para que possamos mudar esse cenário.

Para mais, um aspecto da justiça transicional completamente negligenciado pelo Brasil é a responsabilização dos agentes públicos no âmbito civil, administrativo e penal. Apesar do relatório da CNV ter indicado nominalmente os agentes do Estado envolvidos na perpetração de crimes durante a ditadura, recomendando a apuração dos fatos no âmbito judicial, a interpretação que o STF dá à Lei da Anistia acaba por impedir a persecução penal. A impunidade, então, permeia o seio de nossa democracia e transmite uma mensagem clara: no Brasil, a lei não se aplica igualmente a todos.

Assim, quando em comparação com os demais países estudados ao longo desse trabalho, fica evidente que o Brasil escolheu uma trajetória diferente, privilegiando a amnésia, a impunidade, a corrupção e a violência. Fica claro que essa transição política mal-acabada tem efeitos diretos na democracia vivida pelos brasileiros: o legado da ditadura pode ser visto claramente no atual cenário político que hoje vivemos, no qual impera a corrupção, a impunidade e a indiferença com os direitos individuais e com os princípios democráticos. 
No presente trabalho, foi possível constatar que somente quando os aspectos da justiça transicional são trabalhados em conjunto é que se obtêm progressos efetivos na valorização dos direitos humanos e no fortalecimento da democracia. Portanto, a luta pela implementação do processo transicional no país é medida que se impõe.

Buscar a verdade e a memória, lutar pelo reconhecimento das vítimas da ditadura enquanto cidadãos que exerceram seu direito de resistência ante um governo autoritário, exigir que os fatos sejam esclarecidos perante a justiça e que as instituições que permitiram que a tortura fosse o modus operandi estatal sejam reformadas é dever de todos. Assim, talvez chegue o dia em que o Estado brasileiro não somente registre a existência de direitos, mas garanta-os.

Se olharmos ao nosso redor e tentarmos seguir os passos trilhados pelas nações vizinhas, certamente estaremos escolhendo um caminho rumo a um futuro mais democrático e igualitário. Quem sabe assim chegará o dia em que esse período traumático de nossa história será, finalmente, velado e sepultado, e deixe como lembrança apenas lições para que, no futuro, tamanha atrocidade não se repita em nosso país e para que saibamos sempre zelar pela democracia e pelo respeito à dignidade humana.

\section{Referências}

ABRÃO, Paulo; TORELLY, Marcelo D. As dimensões da justiça de transição no Brasil, a eficácia da Lei de Anistia e as alternativas para a verdade e a justiça. In: PAYNE, Leigh A.; ABRÃO, Paulo; TORELLY, Marcelo D. (Org.). A anistia na era da responsabilização: o Brasil em perspectiva comparada. Brasília: Ministério da Justiça, Comissão de Anistia; Oxford: Oxford University, Latin American Centre, 2011. p. 212-248. Disponível em: <http://www.portalmemoriasreveladas. arquivonacional.gov.br/cgi/cgilua.exe/sys/start.htm?infoid=17\&sid=4> . Acesso em: 17 maio 2015. 
ANISTIA INTERNACIONAL. Informe 2014/2015: O estado dos direitos humanos no mundo. Rio de Janeiro: Al, 2015. Disponível em: <https:// anistia.org.br/direitos-humanos/informes-anuais/o-estado-dos-direitoshumanos-mundo-20142015/>. Acesso em: 14 maio 2015.

BAGGIO, Roberta Camineiro. Anistia e reconhecimento: o processo de (des)integração social da transição política brasileira. In: PAYNE, Leigh A.; ABRÃO, Paulo; TORELLY, Marcelo D. (Org.). A anistia na era da responsabilização: o Brasil em perspectiva comparada. Brasília: Ministério da Justiça, Comissão de Anistia; Oxford University, Latin American Centre, 2011. p. 250-277. Disponível em: <http://www. portalmemoriasreveladas.arquivonacional.gov.br/cgi/cgilua.exe/sys/ start.htm?infoid=17\&sid=4>. Acesso em: 17 maio 2015.

BRASIL. Comissão Nacional da Verdade. Brasília: CNV, 2014. v. 1.

BRASIL. Supremo Tribunal Federal. Ação de Descumprimento de Preceito Constitucional n. 153. Relator: Ministro Eros Grau. Brasília, 29 abr. 2010. Disponível em: <http://redir.stf.jus.br/paginadorpub/ paginador.jsp?docTP=AC\&docID=612960>. Acesso em: 24 ago. 2015.

BURT, Jo-Marie. Desafiando a impunidade nas cortes domésticas: processos judiciais pelas violações de direitos humanos na América Latina. In: REÁTEGUI, Félix (Org.). Justiça de transição: manual para a América Latina. Brasília: Ministério da Justiça, 2011. p. 307-335. Disponível em: <http://www.dhnet.org.br/verdade/resistencia/a_pdf/ manual_justica_transicao_america_latina.pdf>. Acesso em: 11 jun. 2015.

ENGSTROM, Par. A anistia e o sistema interamericano de direitos humanos. In: PAYNE, Leigh A.; ABRÃO, Paulo; TORELLY, Marcelo D. A anistia na era da responsabilização: o Brasil em perspectiva comparada. Brasília: Ministério da Justiça, 2011. p. 102-139.

Disponível em: <http://www.portalmemoriasreveladas.arquivonacional. gov.br/cgi/cgilua.exe/sys/start.htm?infoid=17\&sid=4>. Acesso em: 17 maio 2015.

GOMES, José Maria. Globalização dos direitos humanos, legado das ditaduras no Cone Sul Latino-Americano e justiça transicional. Direito, 
Estado e Sociedade, Rio de Janeiro, n. 33, p. 85-130, jul./dez. 2008. Disponível em: <http://www.jur.puc-rio.br/revistades/index.php/ revistades/article/view/240>. Acesso em: 05 abr. 2015.

ORWELL, George. 1984. São Paulo: Companhia das Letras, 2014.

OLSEN, Tricia D.; PAYNE, Leigh A.; REITER, Andrew G. As implicações políticas dos processos de anistia. In: PAYNE, Leigh A.; ABRÃO, Paulo; TORELLY, Marcelo D. (Org.). A anistia na era da responsabilização: o Brasil em perspectiva comparada. Brasília: Ministério da Justiça, 2011. p. 542-571. Disponível em: <http://www. portalmemoriasreveladas.arquivonacional.gov.br/cgi/cgilua.exe/sys/ start.htm?infoid=17\&sid=4>. Acesso em: 17 maio 2015.

PARENTI, Pablo F. A aplicação do direito internacional no julgamento do terrorismo de Estado na Argentina. Revista Anistia Política e Justiça de Transição, Brasília, 2011, n. 4, p. 32-55, jul./dez. 2010. Disponível em: <http://portal.mj.gov.br/main.asp?Team=\%7B67064208D044-437B-9F24-96E0B26CB372\%7D>. Acesso em: 23 abr. 2015.

PALERMO, Pablo Galain. El proceso de justicia de transición em Uruguay. In: TOSI, Giuseppe et al. (Org.). Justiça de transição: direito à justiça, à memória e à verdade. João Pessoa: UFPB, 2014. p. 157184. Disponível em: <https://www.justica.gov.br/central-de-conteudo/ anistia/anexos/justica-transicao_versao-final.pdf/@@download/file/ Justica\%20Transicao_Vers\%C3\%A30\%20final.pdf>. Acesso em: 19 abr. 2016.

PEIXOTO, Claudia C. Tomazi. Anistia, memória e direitos humanos: a experiência recente do Brasil à luz dos casos argentino e uruguaio. Revista Internacional de Direito e Cidadania, Erechim, v. 4, n. 11, p. 9-23, out. 2011. Disponível em: <http://reid.org.br/arquivos/0000027901-claudia_reid-11.pdf>. Acesso em: 05 abr. 2015.

PEREIRA, Pamela. Os caminhos da judicialização: uma observação sobre o caso chileno. In: REÁTEGUI, Félix (Org.). Justiça de transição: manual para a América Latina. Brasília: Ministério da Justiça, 2011. p. 291-305. Disponível em: <http://www.dhnet.org.br/ 
verdade/resistencia/a_pdf/manual_justica_transicao_america_latina. pdf>. Acesso em: 11 jun. 2015.

ROHT-ARRIAZA, Naomi. Impunidade na América Latina: tribunais nacionais e desafios ainda existentes. In: PAYNE, Leigh A.; ABRÃO, Paulo; TORELLY, Marcelo D. (Org.). A anistia na era da responsabilização: o Brasil em perspectiva comparada. Brasília: Ministério da Justiça, 2011. p. 140-160. Disponível em: <http://www. portalmemoriasreveladas.arquivonacional.gov.br/cgi/cgilua.exe/sys/ start.htm?infoid=17\&sid=4>. Acesso em: 17 maio 2015.

SILVA FILHO, José Carlos Moreira da. Justiça de transição: da ditadura civil-militar ao debate justransicional. Porto Alegre: Livraria do Advogado, 2015.

SILVA FILHO, José Carlos Moreira da. Memória e reconciliação nacional: o impasse da anistia na inacabada transição democrática brasileira. In: PAYNE, Leigh A.; ABRÃO, Paulo; TORELLY, Marcelo D. (Org.). A anistia na era da responsabilização: o Brasil em perspectiva comparada. Brasília: Ministério da Justiça, 2011.

Disponível em: <http://www.portalmemoriasreveladas.arquivonacional. gov.br/cgi/cgilua.exe/sys/start.htm?infoid=17\&sid=4>. Acesso em: 17 maio 2015. p. 278-307.

VAN ZYL, Paul. Promovendo a justiça transicional em sociedades pósconflito. In: REÁTEGUI, Félix. (Org.). Justiça de Transição: manual para a América Latina. Brasília: Ministério da Justiça, 2011. p. 47-71. Disponível em: <http://www.dhnet.org.br/verdade/resistencia/a_pdf/ manual_justica_transicao_america_latina.pdf>. Acesso em: 11 jun. 2015.

YACOBUCCI, Guilhermo J. El juzgamiento de las graves violaciones de los derechos humanos en la Argentina. In: GOMES, Luiz Flávio; MAZZUOLI, Valério de Oliveira. Crimes da ditadura militar: uma análise à luz da jurisprudência atual da Corte Interamericana de Direitos Humanos. São Paulo: Revista dos Tribunais, 2011. p. 21-47.

Recebido em: 24/07/2016

Aprovado em: 07/10/2016 